\title{
A GRID THEORY OF STRESS IN POLISH*
}

\author{
Jerzy RUBACH \\ Free University, Amsterdam, The Netherlands and University of Warsaw, Poland
}

\author{
Geert E. BOOIJ
}

Free University, Amsterdam, The Netherlands

Received January 1985; revised version May 1985

\begin{abstract}
This paper presents a survey of the Polish stress system and explores the theoretical consequences of this system for a number of current issues in phonological theory: the notion 'extrametricality'; grids versus trees, and principles of eurhythmicity. It is argued that the metrical grid is superior to the metrical tree for the description of stress patterns in Polish words and phrases. This analysis of Polish stress has also consequences for the typology of stress systems. Furthermore, the analysis of stress in Polish compounds substantiates the claim of current prosodic theory that phonological structure need not be isomorphic to morphological structure.
\end{abstract}

\section{Introduction}

The aim of this paper is twofold: first, to bring into the current linguistic debate the stress system of Polish, and, second, to discuss the theoretical concepts of present day metrical phonology inasmuch as they are relevant for the data from Polish.

To attain the first end, we give a complete overview of all the issues in the phonology of Polish stress at the level of words and phrases. We mention also those problems for which we do not have any interesting solutions to suggest (cf. section 9). We acknowledge the influence of the pioneering

* This paper is part of research project no. LETT $83 / 7$, Faculty of Letters, Free University Amsterdam. J. Rubach would like to thank the Dutch Organization for the Advancement of Pure Scientific Research (ZWO), whose grant made it possible for him to spend a period of four months in the Department of General Linguistics, Free University Amsterdam, where this paper was prepared. The authors would also like to thank Morris Halle and Grzegorz Dogil for their comments on an earlier draft of this paper. Needless to say, this does not necessarily mean that they agree with the contents of this paper. 
work of Dogil (1979) which presents a metrical analysis of emphasis in Polish but we hasten to add that the range of data covered in this paper as well as their interpretation are different, which is a natural consequence of the fact that Dogil's aim and theoretical framework are different from ours.

As regards the theoretical concepts in the current linguistic debate, we look at the problem of the arboreal versus the grid frameworks, we discuss perfect grid and euphony rules as well as stress clashes and eurhythmicity and we demonstrate the usefulness of the concept of extrametricality for the analysis of Polish. We acknowledge here the influence of the truly illuminating works of Halle and Vergnaud (1984), Prince (1983), Selkirk (1984), and others.

We want to investigate the descriptive and explanatory power of the grid with respect to Polish stress. It appears that the grid is an adequate mechanism, in particular for the description of secondary stress in Polish, which can be seen as a manifestation of rhythm rather than of stress strictu sensu. We do not wish to claim that our analysis has settled the theoretical issue mentioned above. It is meant as a contribution to this discussion.

We operate with the prosodic categories: the syllable and the phonological word (referred to as mot and abbreviated as $m$ ). The latter, whose status as a category is at present subject to much debate, is the domain of syllabification in Polish and does not necessarily coincide with words in the grammatical sense (cf. Booij and Rubach (1984)).

\section{Overview of data}

Polish is a stress-timed language, although, admittedly, it is not as salient an example of this class of languages as, for instance, English and Russian are. Vowel reduction is possible, and indeed frequent, but only in rapid speech (cf. Rubach (1974)).

As is well known, primary stress in Polish falls on the penult both in inflected stems and in derived words. Therefore its place changes under suffixation :

(1) reporter 'reporter' (nom.sg.) : reporter $+a$ (gen.sg.), reporter $+\stackrel{1}{\text { owi }}$ (dat. sg.) $\ldots$, reporter $+s k+i$ (Adj., nom.sg.), reporter $+s k+i^{1}$ go (Adj., gen. sg.), etc. 
Let us immediately note two technical matters. First, we shall use numbers: 1 for primary stress, and 2 for rhythmic weak stress (which we discuss below) rather than the familiar accent signs. This is to avoid confusion with the diacritic accent on the letter $\delta[u]$. Second, the letter $i$ is not vocalized before vowels. It functions as a diacritic to show that the preceding consonant is palatal. After labials and before vowels $i$ appears as [j] (cf. Rubach (1984a) for a concise discussion of the correspondence between letters and sounds in Polish).

It is also well known that in some cases Polish has an antepenultimate main stress. These cases are discussed in section 3 under the heading 'Extrametricality'.

What is less known, or at least what has been neglected in the metrical literature, is the fact that Polish has a regular pattern of alternating rhythmic stresses. They are mentioned by Gaertner $(1938: 84)$ and discussed in quite some detail by Dłuska (1957) and (1974). In her (1957) paper, Dłuska draws attention inter alia to the fact that (p. 97): 'zawsze jednak jeden akcent od drugiego musi przedzielać co 'najmniej jedna nieakcentowana sylaba' (it is always, however, the case that one stress must be separated from the other by at least one unstressed syllable, my translation, JR). The same conclusion emerges from her (1974) monograph (2nd edition). There, she looks at the length of vowels and observes that the vowel under primary stress is the longest in a word and other vowels form an alternating pattern of longer and shorter vowels. We thus have, for example:

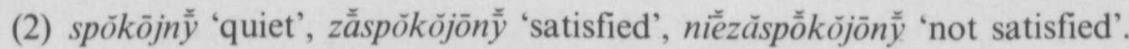
(Dłuska $(1974: 16))$

The reader will have noticed that the alternating pattern is disturbed by the lengthening of the word final vowel. Dluska explains that this is specific to the dialect of Cracow and it is a phonetic process affecting word final vowels if they stand in an open syllable. In other dialects of Polish the word final vowel is short (Dluska (1974: 15)). Dluska's observations and our own findings establish the phonetic pattern given in (3) below, where the capital $X$ stands for stress (rhythmic or primary) and the small $x$ represents the lack of stress on a vowel:

(3a) $X \times X \times$

(3b) $X \times x \times X x$ 
These patterns recur in words and in phonological phrases.

It is also important to point out that rhythmic stresses in Polish are all optional, i.e., they are present in slow and careful speech but disappear in rapid speech. The only stress that is never affected, regardless of the tempo of speech, is the primary stress, provided that it occurs on words of two or more syllables. ${ }^{1}$ Thus, in rapid speech, we have a flattening of rhythmic structure with the notable characteristic that internal stresses are likely to be evened out sooner than the initial stress. Given a string such as that in (4a), we obtain the variants in (4b) and (4c) with the increase of the tempo of speech:
(4a) $X \times X \times X x$
(4b) $X x x x X x$
(4c) $x \quad x \quad x \quad x \quad X x$

Dhuska (1974: 20) points out that the primary stress is established for words, i.e., it is the penult of a word regardless of whether the word is followed by clitics. However, rhythmic stresses are established for phonological phrases (Dłuska's zestroje akcentowe (1974: 28)) and they are distributed rhythmically among all items in a phrase. In this paper we follow Dłuska (1974) in her understanding of zestrój akcentowy, which we term 'phonological phrase'. A phonological phrase consists of one word carrying the main stress and, optionally, of monosyllabic words which normally are not major lexical categories. They can thus be:

(5) pronouns, e.g., ja 'I', on 'he', nas 'us';

pronominal determiners, e.g., mój 'my', nasz 'our', ich 'their';

prepositions, e.g., na 'on', do 'to', od 'from';

conjunctions and particles, e.g., ze 'that', gdy 'if', jak 'how';

clitics, e.g., by 'would', się '-self', etc.

These monosyllabic words may appear before or after the main stress word. In what follows we shall limit our discussion to the problem of word and phrase stress in the sense just outlined.

The data used in this paper are drawn in part from Dłuska ((1957) and (1974)) and in part from the observations and noninstrumental experiments

1 Dłuska notes that in poetry major category words may also be unstressed provided that they are monosyllabic: deszcz dzwôni 'the rain is ringing' (Dłuska (1974: 25)). 
(lists of words, read by native speakers, etc.), carried out by one of the authors, Jerzy Rubach, who is a native speaker of Polish. The paper has been subdivided into sections to make the presentation clear. In section 3 , which follows immediately below, we discuss extrametricality.

Section 4 presents the Main Stress Rule and looks at Prince's End Rule (Prince (1983)). Further, in sections 5 and 6 we discuss euphony rules and the concept of the perfect grid. Section 7 is devoted to compounds: their stress and structure from the point of view of morphology and phonology. It prepares the ground for a discussion of stress clashes and eurhythmicity in section 8 . The next two sections present rule governed subregularities in the system of Polish. The conclusion in section 11 is a summary of the most important theoretical results.

\section{Extrametricality}

Halle and Vergnaud (1984) observe that there are two classes of words in Polish which have antepenultimate stress:

Class I (feminine nouns):

(6a) gramátyk $+a$ 'grammar' (nom.sg.), gramatyk $+i$ (gen.sg.)

(6b) gramatyk + ami (instr.pl.), gramâtyk (gen.pl.)

We add some more examples : logik $+a$ 'logic', anglisty $k+a$ 'English studies', fizyk $+a$ 'physics', okolic $+a$ 'surroundings', etc.

Class II (masculine nouns):

(6c) uniwersytet 'university' (nom.sg.)

(6d) uniwersytet $+u$ (gen.sg.), uniwersytet $+\stackrel{1}{\text { ami }}$ (instr.pl.)

Likewise (we add): prezydent 'president', komitet 'committee', autorytet 'authority', dżentelmen 'gentleman', Waszyngton 'Washington', etc. 
It is to be noted that class I words have antepenultimate stress only when monosyllabic suffixes are added: the data in (6a). If the suffix is disyllabic or if it is manifested as zero on the surface, the stress is penultimate: the data in (6b). Class II words are different in that antepenultimate stress is found only in the nom.sg., where the ending is zero in terms of phonetic representation.

To handle these facts, Halle and Vergnaud propose that stems of class I words assign extrametricality to the syllable which follows while the words in class II carry extrametricality on the last syllable of the stem:

(7) 'Mark as extrametrical the last stem syllable in masculine nouns and the post-stem syllable in feminine nouns.' (Halle and Vergnaud (1984))

This is an ingenious solution. Halle and Vergnaud point out that the intricate pattern of penultimate stressing falls out from the rule just given and the general principles governing extrametricality. In the instr.pl. gramatyk +ami rule (7) is correctly inapplicable because the suffix which has been attached is disyllabic, hence the syllable which follows the stem is not the final syllable of the constituent, and, by general principle, only constituentfinal entities may be extrametrical. On the other hand, in the gen.pl. gramatyk there is no suffix following the stem, hence (7) cannot apply. The prediction is that in both gramatyk +ami (instr.pl.) and gramatyk (gen.pl.) the stress should be penultimate (by the Main Stress Rule, see section 4 below), which is borne out.

In class II words the last syllable of the stem becomes extrametrical by (7). In oblique cases, where endings are appended, the stem final syllable is not constituent final. No extrametricality is therefore assigned and hence the stress is penultimate, as shown in (6d).

However, Halle and Vergnaud's solution runs into some difficulty when one considers a wider range of data. First, and this is not particularly important, there are also a number of masculine nouns which belong to class I rather than to class II:

(8) penultimate stress:

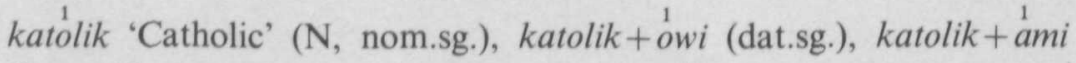
(instr.pl.), vs. antepenultimate stress :

katolik $+a$ (gen.sg.), katolik $+u$ (voc.sg.), katolic $+y$ (nom.pl.), etc. 
Likewise: historyk 'historian', fanatyk 'fanatic', teoretyk 'theoretician', logik 'logician', egzamin 'examination', etc.

The data in (8) show that class I words form a fairly arbitrary group: they can be both feminine and masculine. However, this is of no particular significance. Halle and Vergnaud point out correctly that words with antepenultimate stress are in fact lexically governed exceptions, hence the membership of an item in one or the other class is arbitrary. The exceptional nature of antepenultimate stress is also confirmed by the fact that these words tend to regularize. For instance, some speakers of Polish have the regular autorytet and egzamin instead of autorytet and $\stackrel{1}{\text { egzamin. }}$.

A second, and this time a more important observation is that rule (7) should not apply when stems such as those in (6a) or (8) are followed by derivational suffixes, even if these suffixes are monosyllabic. We thus have a regular penultimate stress in derivatives from the words in (6a) and (8):

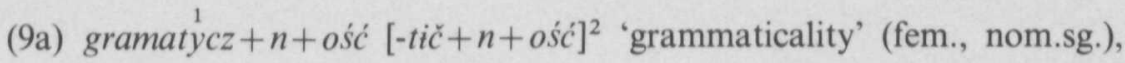
$\stackrel{1}{1}{ }^{\prime} i c z+n+o s ́ c ́$ 'logical reasoning' (fem., nom.sg.)

(9b) katolic $+y z m[k a t o l ' i c+i z m]$ 'Catholicism' (masc., nom.sg.), historyc + $y z m$ 'historicism' (masc., nom.sg.), etc.

Given rule (7) we would expect an antepenultimate stress since the relevant stems are followed by a single syllable, at least on the surface. It looks like one would have to say that extrametricality holds only under inflection but not under derivation. However, to say this is to deprive the concept of extrametricality of its explanatory power. We suggest a solution along different lines.

Observe that the stems in $(9 a)$ show effects of palatalization on the stem final consonant: an underlying // $/ /$ of gramatyk $+a$ 'grammar' changes into surface [č] before $n$. This and a number of other facts which we cannot

2 We use double slashes for underlying representation, single slashes for intermediate representations and square brackets for phonetic forms. Note also the transcription:

[c dz]: alveolar affricates;

[č dž] : postalveolar affricates;

[ć dź] : prepalatal affricates, and

[ś ź ń]: prepalatal fricatives and a nasal. 
discuss here (but see Rubach (1984a)) lead to the conclusion that $n$ is actually $/ /$ in $/ /$. The change of $/ / \mathrm{k} / /$ into [c] is effected by the rule of 1 st Velar Palatalization and the high lax vowel $/ / \mathbf{l} / /$ is subsequently deleted by a postcyclic rule of Yer Deletion (cf. Rubach (1984a)). Assume now that rule (7) applies before Yer Deletion. The stem gramatyk 'grammar' will then be followed by more than one syllable: /-č + in + osć/ gramatyczność 'grammaticality' and (7) will be correctly inapplicable.

The words in (9b) can be explained along the same lines. For reasons entirely independent of the extrametricality problem (cf. Rubach (1984a)), Polish zero endings of the nom.sg. and the gen.pl. are represented as the high lax vowel $/ / \mathfrak{\mathbf { t }} / /$. This vowel, like that of $/ / \mathrm{in} / /$, is subject to Yer Deletion and hence it cannot be seen on the surface. However, prior to Yer Deletion, complex stems such as that of katolicyzm 'Catholicism', which comes from underlying $/ /$ katolik $+\mathrm{izm} / /$, are followed by $/ / \check{\mathbf{t}} / /$. Consequently, the root stem katolik is followed by two syllables at the relevant stage of derivation: /katolic $+\mathrm{izm}+\mathbf{i} /$ 'Catholicism'. Thus (7) is correctly inapplicable. We conclude that Extrametricality Assignment (7) must apply prior to the rule of Yer Deletion.

What happens to the nom.sg. katolik 'Catholic' and the gen.pl. gramatyk 'grammar' then? At the stage prior to Yer Deletion they are represented as / katolik $+\tilde{i} /$ and /gramatik $+\check{i} /$, respectively. Rule (7) applies and makes $/ \check{\mathbf{i}} /$ extrametrical. The yer $/ \tilde{\mathbf{t}} /$ is subsequently deleted by Yer Deletion and the stress is penultimate, as required. In other paradigmatic cases such as katolik $+a$ (gen.sg.) and gramatyk $+a$ (nom.sg.) the vowel is not deleted and hence the stress is antepenultimate.

An apparent complication arises for class II words in (6c). If they were assigned extrametricality by (7), now ordered before Yer Deletion, the result would be incorrect: uniwersytet 'university' being a masculine noun carries the inflectional yer as well / universitet $+\check{\mathbf{z}} /$. Recall that here - et must be made extrametrical. Things will fall into place if class II words are assigned extrametricality after Yer Deletion. The rule they undergo must therefore be different from (7) since it applies later. We propose to break up Halle and Vergnaud's rule (7) into two rules preserving at the same time the basic insight and the form of (7). Thus we have rule (10) ordered before Yer Deletion and rule (11) ordered after Yer Deletion:

(10) Extrametricality I:

Mark as extrametrical the post-stem syllable in class I nouns. 
(11) Extrametricality II :

Mark as extrametrical the last stem syllable in class II nouns. ${ }^{3}$

Let us note that the assumption that Extrametricality (10) applies before Yer Deletion does not mean that the Main Stress Rule (see next section) must also apply before Yer Deletion. In fact, the Main Stress Rule applies after Yer Deletion.

Are we losing much by breaking up Halle and Vergnaud's rule into two? Hardly. Note that the two subrules of (7) apply to different sets of data and they do not have much in common with each other.

There is an interesting aspect of our analysis yet to be evaluated. The high lax vowels $/ / \mathbf{i} / /$ and $/ / \breve{\mathbf{t}} / /$, which are labeled 'yers' in Rubach (1984a), are 'abstract' in the sense of absolute neutralization. They never surface phonetically as [i $\mathrm{i}]$. What we see on the surface is the vowels [i i] derived by Imperfective Tensing and the vowel [e] derived by Lower (both of these rules are discussed in detail in Rubach (1984a)). In many instances no vowel at all appears on the surface: these are the cases where Yer Deletion applies. However, we do see phonetic effects of other rules which apply in the environment of the abstract yers. One such effect has been given above: the palatalization of $/ / \mathbf{k} / /$ to [c] in the words of (9a), another is the behaviour of class I words towards extrametricality. Rule (10) can therefore be regarded as yet another argument for postulating absolutely neutralizeable yers in Polish. It is thus an argument for abstract representations. What is interesting is how various interactions of rules which have nothing to do with each other (e.g., 1st Velar Palatalization, $k \rightarrow \check{c}$, and Extrametricality I) can confirm an analysis whose value may seem dubious at first glance on grounds of a very high degree of abstractness.

\section{Main Stress Rule}

We are now passing to the core of the Polish stress system. We wish to demonstrate, inter alia, that this system can be described correctly and insightfully (inasmuch as is possible) within the framework of the gridtheory. In fact, this description can claim some advantage over the classic

3 Franks (1985) is a variant of our analysis, worked out independently. Our rule II is necessary because of the orthodox interpretation of the Peripherality Condition. If it is a visibility condition, as Franks suggests, rule II can be replaced by lexical marking of these stems as extrametrical in the last syllable. 
arboreal account (Selkirk (1980)), where instead of grids metrical trees along with the strong-weak labeling are postulated.

We shall assume with Prince (1983), Halle and Vergnaud (1984), Selkirk (1984) and other researchers that there is a universal principle of grid construction which assigns demibeats (Selkirk's term) or asterisks (Halle and Vergnaud's term) to every syllable of a constituent. These beats are what Halle and Vergnaud have called 'place holders' at the zero level. Their sole function is to express an alignment with syllables, i.e., they do not denote any degree of stress.

Given this assumption, the basic grid of a trisyllabic word such as reporter 'reporter' is as in (12a) below and the Main Stress Rule (to be formulated later) must indicate that the penultimate syllable is stronger than the other syllables of this word, i.e., it must produce the structure in (12b):

(12a) reporter

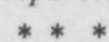

(12b) reporter

***

We have noted that the Main Stress Rule of Polish is sensitive to the information: 'end of a word' and is not affected by whatever other words may follow in a given phonological phrase. Thus the stress of reporter is the same as that of (reporter ten) 'this reporter'. The items that may follow reporter in the same phonological phrase are mots (phonological words). The Main Stress Rule is now formulated as in (13), where we make reference to the end of mot rather than to the traditional \# boundary which does not exist in the phonological framework within which we work:

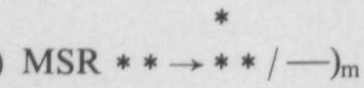

Observe that MSR stresses, i.e., assigns a beat to words which have two or more syllables. This is intentional. We claim that MSR should not apply to monosyllables at all. There are several reasons which lead us to make this assumption.

First, one of the most sálient results of recent work in metrical phonology is the emphasis laid on the fact that stress is relational. Consequently, there is nothing to be gained by postulating a rule which would assign stress to 
monosyllabic words. A syllable is stressed only to the extent that it stronger, louder, on a higher pitch, etc. than some other syllable. In the absence of this other syllable assignment of stress is contentless. Admittedly, something needs to be said about constituents which contain several monosyllabic words since then the relational nature of stress can be, and in fact always is, brought out. We address this problem in the last paragraphs of this section.

Second, it is a fact of Polish that monosyllabic words in a phonological phrase carry no stress if they are followed by a word whose first syllable is stressed. In (14) below we give one example with the interrogative particle $c z y$ 'whether', one instance of a prepositional phrase and one compound, whose constituents are indicated by $m$ markings for mot (in the first two examples this is obvious). Grids are constructed above words:

(14)

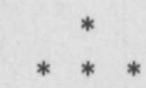

czy piszesz 'are you writing'
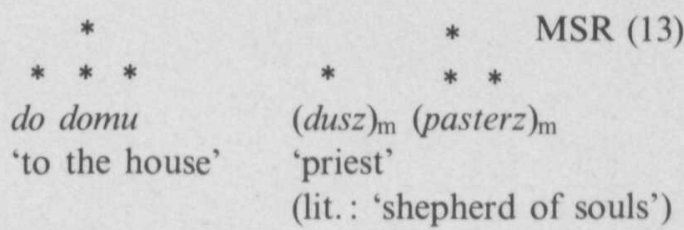

Given that MSR has the form shown in (13), nothing needs to be said about the lack of stress on the monosyllabic words in (14). Had we assigned stress to monosyllables, we would have had to postulate a rule of destressing (defooting). This rule would have had to apply in the context before a stressed syllable of the major category item. An additional complication in the statement of this rule would arise due to the fact that destressing would have had to apply also in the context after a foot. For example, the words nasz 'our' and ta 'this' are stressless in (15):

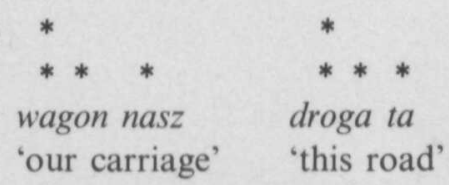

MSR (13)

Again, given MSR as in (13), nothing needs to be said about nasz and ta in the phrases in (15).

Third, monosyllabic words which enter into phonological phrases get 
rhythmic stress in accordance with the requirement of keeping an alternating pattern (see next section). Thus in (16) below the monosyllabic words on 'he', by 'would', wam 'you' (oblique case) and to 'this' can be either stressed or unstressed, depending on their position in the phrase. The sentence in (16) means 'He would do this for you' and it may appear in four different configurations from the point of view of word order :

(16a) $\stackrel{2}{O}^{2}$ by wam to zrobil.

(16b) $\mathrm{To}^{2}$ by ${ }^{2}$ n wam zrobil.

(16c) Zrobiłby on wam to.

(16d) Zrobil on wam by to.

On the interpretation of MSR proposed in this paper, the pattern of alternating weak stresses is generated by a rule which adds such stresses, a rule which is independently motivated (see next section).

There is an interesting further observation to be made here. One would ordinarily assume that languages with penultimate stress (such as Polish) are different from languages with word final or word initial stress (e.g., French, Czech) in that they have an additional rule which marks the last syllable of a word as extrametrical (Prince (1983: 47)). The universal End of Domain Rule (End Rule) applying in its right-hand version would then place stress correctly since it stresses syllables which are at an edge of a constituent :

(17) reporter 'reporter' $\rightarrow$ repor(ter $)_{\mathrm{ex}}$ by Word Final Extrametricality $\rightarrow$ repor (ter) $)_{\mathrm{ex}}$ by End Rule (right-hand version); also : potok 'stream' $\rightarrow$ $p o(t o k)_{\mathrm{ex}} \rightarrow p^{1}(t o k)_{\mathrm{ex}}$, etc.

However, Halle and Vergnaud (1984) have concluded that Polish cannot be analysed along the linęs which one would generally assume for penultimate stress languages. Halle and Vergnaud's argument is that in words with antepenultimate stress (see section 3 above) Word Final Extrametricality would not be able to apply. The crucial observation here is that these words 
have to undergo an extrametricality rule of their own (rules 10) and (11) above). In addition, they would have to undergo Word Final Extrametricality, a situation which is not permitted by the theory (one of the extrametrical syllables would not be word-final). Once we concede that Word Final Extrametricality cannot be a rule of Polish, it follows automatically that End Rule cannot apply in Polish either since one cannot work without the other in a language that has penultimate stress.

Finally let us address the question of what happens when we have a sequence of monosyllabic words in a phonological phrase. In phrases such as nasz dom 'our house' or na dach 'on the roof' the words dom 'house' and dach 'roof' are stronger.

Observe that Polish must have a Nuclear Stress Rule whose form is essentially the same as in English:

(18) Nuclear Stress Rule (NSR):

Add a beat to the rightmost major category word.

This rule applies in all kinds of syntactically derived constituents. For example, it is responsible for the fact that rower 'bicycle' has the greatest degree of stress in a sentence such as Janek kupil rower 'John bought a bicycle'. We suggest that the same rule be used to account for stress in sequences of monosyllables in a phrase:

\begin{tabular}{|c|c|}
\hline $\begin{array}{l}\text { nasz dom } \\
\text { 'our house' }\end{array}$ & $\begin{array}{l}\text { na dach } \\
\text { 'on the roof' }\end{array}$ \\
\hline
\end{tabular}

\section{Beat Addition}

We are now in a position to look at Polish rhythmic stress. As pointed out in section 2, it forms an alternating pattern. An obvious solution here is to make use of the universal beat addition rule:

(20) Beat Addition (BA):

Add a beat to construct a perfect grid.

Beat Addition is a euphony rule in terms of Selkirk (1984). It constructs 
a perfect grid, which means that it avoids stress clashes. ${ }^{4}$ Taking the word propagand $+a$ 'propaganda' as an example, we obtain the following derivation :

(21) propaganda

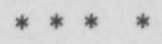

$* * \quad$ MSR (13), BA (20)

Here and below, whenever ambiguity may arise, we circle the beats added by Beat Addition.

Notice that (21) presents a problem since the greater prominence of the main stress has not been preserved. One obvious move to make at this point is to apply BA before MSR :

(22) propaganda

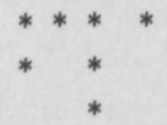

BA (20)

MSR (13)

Unfortunately, the derivation in (22) cannot be maintained. As will become clear towards the end of this section, MSR must crucially apply before Beat Addition.

There are two solutions of the problem at hand which are largely notational variants of each other in our framework of analysis :

(i) Assume that main stress in Polish is a three level derivation. This would be in keeping with Halle and Vergnaud's (1984) analysis. MSR is then a level three rather than a level two rule. ${ }^{5}$ The beat on level

4 A stress clash is defined as the presence of two beats in adjacent columns without an intervening beat at the immediately preceding level, for example: $*^{*} * *$ or $* *^{*} * * *$. A perfect grid would look as follows: $* * * *, *^{*}+\stackrel{*}{* *}$, etc.

5 In Halle and Vergnaud (1984) the numbering of these levels would be lower by one as they assume that the basic grids, the 'place holders', are at level 0 rather than at level 1. 
two is supplied by a convention which adds beats to fill in holes in the grid: 'Given the unit S (syllable, vowel, etc.) if $\mathrm{S}$ has an asterisk on row $n$, an asterisk is placed on every row $n-m, o<n<m^{\prime}$ (Halle and Vergnaud (1984)).

(ii) Make use of Selkirk's (1984) Textual Prominence Preservation Condition. The essence of Selkirk's principle is that euphony rules such as Beat Addition may not undo the prominence relations assigned by MSR (i.e., in this instance, more generally, the prominence relations assigned by text-to-grid rules of which MSR is one). Beats are therefore added automatically to the main stress column if the prominence distinction between the main and the rhythmic stresses is going to be lost.

Somewhat arbitrarily we choose solution (ii). Rule (20) is 'exactly the euphony type of rule that Selkirk has in mind. Its ordering after MSR is also very much in keeping with Selkirk's theory: text-to-grid rules (MSR, NSR) must precede euphony rules. The derivation in (21) is now replaced by that in (23):

(23) propaganda

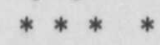

* * $\quad$ MSR (13)

* $\quad$ BA $(20)$

While perfect grid construction is a universal principle, the particular ways of implementing this principle are language specific. Prince (1983) points out that language specific parameters to be fixed are the direction in which the rule applies (left to right or right to left) and whether the mapping starts with a peak $\left\{\begin{array}{l}* \\ *\end{array}\right\}$ or a trough $(*)$. There are four logical possibilities which we quote with some technical alterations after Prince (1983: 48) :

(24a) L-R; trough: $\sigma \sigma \sigma \sigma \sigma \sigma \ldots$ (syllables)

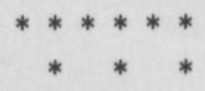

(24b) L-R; peak: $\sigma \sigma \sigma \sigma \sigma \sigma \ldots$
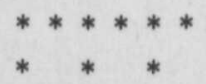
(24c) R-L; trough: ... $\sigma \sigma \sigma \sigma \sigma \sigma$

(24d) R-L; peak: $\ldots \sigma \sigma \sigma \sigma \sigma \sigma$

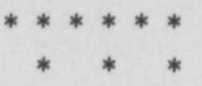

We must decide which of these universally available patterns is appropriate for Polish.

The derivation of rewolucjonista 'revolutionary' $(\mathrm{N})$ in (25) below leaves only two possibilities open: Polish is either $\{\mathrm{R}-\mathrm{L}$; through $\}$ or $\{\mathrm{L}-\mathrm{R}$; peak $\}$. The configuration $\{\mathrm{R}-\mathrm{L}$; peak $\}$ would result in a stress clash, hence it is systematically impossible. The parameters $\{\mathrm{L}-\mathrm{R}$; trough $\}$ would leave the initial syllable unstressed, which is incorrect:

(25) $\mathrm{L}-\mathrm{R}$; trough (incorrect) rewolucjonista

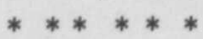

$*$
$\mathrm{R}-\mathrm{L}$; trough or $\mathrm{L}-\mathrm{R}$; peak (correct) rewolucjonista

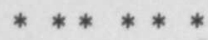

*) $* *$
MSR (13)

BA (20)

We need to look at words consisting of five or seven syllables to discover the exact parameter for Beat Addition. It is clear that in such instances $\{\mathrm{R}-\mathrm{L}$; trough $\}$ would leave the initial syllable unstressed, which is incorrect. The correct derivations of saksofon $+i s t+a$ 'saxophone player' and rewolucj+ $o n+i s t+a m i$ 'revolutionary' (instr.pl.) are obtained if we apply BA from left to right starting with a peak:

(26)

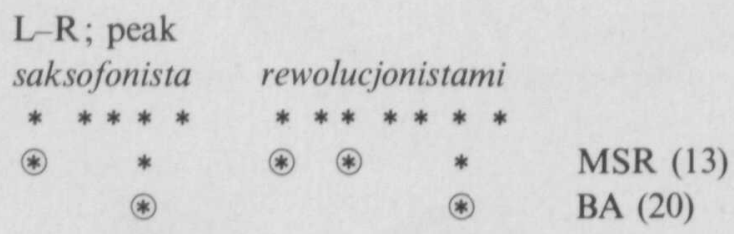

The parameters for constructing a perfect grid in Polish have now been fixed. We replace (20) by (27):

(27) Beat Addition (BA):

Add a beat to construct a perfect grid ( $\mathrm{L}-\mathrm{R}$; peak). 
We now illustrate the operation of BA with the word konstantynopolitanczyk 'inhabitant of Constantinople':

(28) konstantynopolitańczyk (nom.sg.)

$\begin{array}{lllll}* & * & * & * & * * * \\ * & * \quad * & *\end{array}$

$\circledast$

konstantynopolitańczyka (gen.sg.)

*

* $\circledast$

$*$
$\operatorname{MSR}(13)$

BA (27)

MSR (13)

BA (27)

konstantynopolitańczykami (instr.pl.)

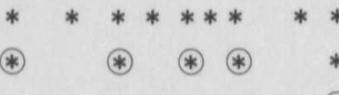

$\operatorname{MSR}(13)$

*

BA (27)

It is also Beat Addition which accounts for rhythmic stressing in phonological phrases. In (29a) below we give a full prosodic structure of the phrase quoted earlier in section 4: 'He would do this for you'. Phonological words $(m o t=m)$ have been gathered into a phonological phrase $(\varphi)$. In the remaining examples in (29) we given only $m$ markings since the prosodic structure in these and other instances which we discuss later in this paper is parallel to that of (29a):

(29a)

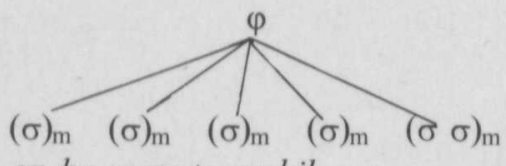

on by wam to zrobil

$\begin{array}{llllll}* & * & * & * & * * & \\ * & & * & & * & \text { MSR }(13) \\ & & & * & \text { NSR }(18) \\ & & & & \text { BA }(27): \text { (circled asterisks) }\end{array}$

(Lit. : 'he', 'would', 'you', 'this', 'do'.)

(29b) to by on wam zrobil

$(*)_{\mathrm{m}}(*)_{\mathrm{m}}(*)_{\mathrm{m}}(*)_{\mathrm{m}} \quad(* *)_{\mathrm{m}}$

$* \quad * \quad * \quad \operatorname{MSR}(13)$

* NSR (18)

BA (27)

(Lit.: 'this', 'would', 'he', 'you', 'do'.) 
(29c) on by to zrobil

$(*)_{\mathrm{m}}(*)_{\mathrm{m}}(*)_{\mathrm{m}}(* *)_{\mathrm{m}}$

(

MSR (13)

NSR (18)

BA (27)

'He would do this.' (Lit.: 'he', 'would', 'this', 'do'.)

(29d) by to zrobil

$(*)_{\mathrm{m}}(*)_{\mathrm{m}} \quad(* *)_{\mathrm{m}}$

* * $\quad$ MSR (13)

NSR (18)

BA (27)

'He would do this.' (Lit.: 'would', 'this', 'do'.)

Certain complications arise when we look at phrases in which monosyllabic words are postposed with respect to the word carrying the main stress. These complications come to light in the configuration where the main stress is followed by an even number of syllables. Rule (27) gives a correct result only in $(30 a-b)$. In ( $30 c-d)$ the output is incorrect :

(30a) zrobil on by wam to

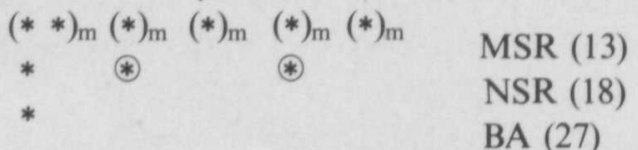

'He would do this for you.' (Lit.: 'do', 'he', 'would', 'you', 'this'.)

(30b) zrobil wam to

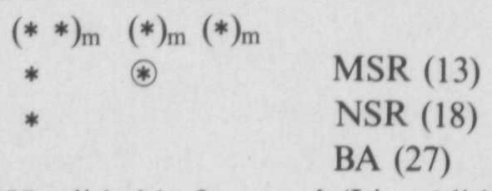

'He did this for you.' (Lit.: 'did', 'you', 'this'.)

(30c) zrobil wam

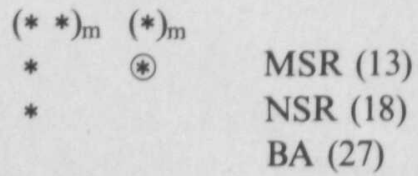

'He did you.' (Lit.: 'did', 'you'.) 
(30d) zrobilby 6 wam to

$(* *)_{\mathrm{m}}(*)_{\mathrm{m}} \quad(*)_{\mathrm{m}}(*)_{\mathrm{m}}$

* $* \quad$ MSR (13)

* NSR (18)

BA (27)

'He would do this for you.' (Lit.: 'do', 'would', 'you', 'this'.)

In (30c) Beat Addition should not apply at all while in (30d) it should add rhythmic stress only on wam 'you'. The correct result is obtained if we assume that Polish has rule (31), whose parameters are: right to left application and starting with a through:

(31) Post-stress BA:

Add a beat to construct a perfect grid (R-L; trough). ${ }^{7}$

Rule (31) gives a correct derivation for all the phrases in (30). Below we derive only those in $(30 c-d)$ where the previous attempt at generating the correct structure was unsuccessful :

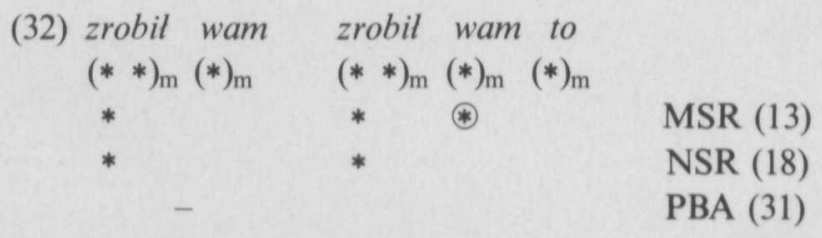

It is now clear that we could not use the option of deriving the correct prominence relations in (23) above by assuming that Beat Addition applies before MSR, as in (22). The main stress in Polish acts as a focus and we must first localize the focus to know how to form the rhythmic pattern.

The assumption that the two Beat Addition rules apply after MSR and that they apply from both ends of the word is not by any means valid for

6 The fact that by is spelled together with the verb here is of no relevance. It is a matter of orthographic convention. In otherwise identical constructions with verbs in the impersonal form, by is spelled separately, e.g., widziano by go 'he would be seen', literal: 'seen', 'would', 'him'.

7 Rule (31) is not entirely symmetrical to rule (27): rule (31) is trough-first, rule (27) is peak-first. 
Polish only. For example, for Dutch also we need to assume that primary stress is assigned before the assignment of secondary stresses. This is motivated by the fact that the location of the primary stress varies, and is sometimes unpredictable, while the location of secondary stresses is always predictable provided that we know where the main stress is. Beat Addition rules for Dutch create a perfect grid with one exception: the first or the last syllable of a word always receives stress, even if this should create a rhythmic lapse (this syllable cannot contain a schwa). The principle of stress clash avoidance is also valid. We thus have grids such as the following:

(33a) main stress on the final syllable:

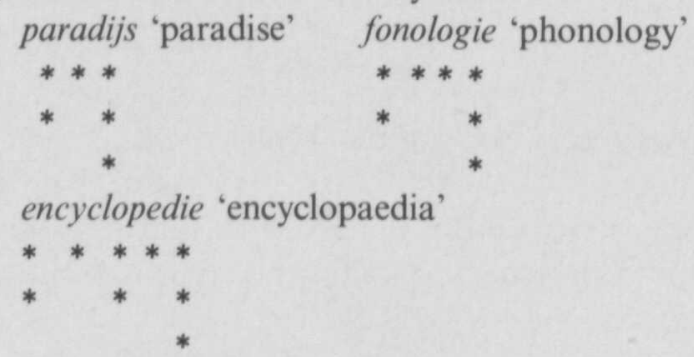

(33b) main stress on the first syllable:

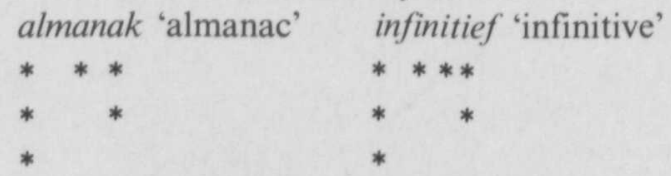

The only difference between Polish and Dutch with respect to Beat Addition is that in Polish Post-stress Beat Addition (31) is a trough-first rule while in Dutch it is a peak-first rule.

The secondary stress patterns of Italian, as described by Scalise and Vogel (1982) are remarkably similar to those of Polish and Dutch. The (largely unpredictable) main stress functions as a focus for secondary stress. The following principles hold for underived and most derived words: there are no stress clashes, words begin with a stressed syllable, and there are no sequences of more than two unstressed syllables.

The fact that Polish, Dutch and Italian words have always stress on the first syllable, if possible, shows that secondary stress in these languages is not a by-product of main stress assignment, as would be expected in an arboreal theory of foot assignment, but an independent principle of rhythmic alternation that is best expressed by a perfect grid rule, since, as Hayes 
(1984: 59) points out, it is grids that represent rhythm (cf. van der Hulst (1984) for similar conclusions).

Finally, the existence of two 'stress trains' has also been reported for Auca, a language of Ecuador (cf. Pike (1964)). In this language a peak-first Beat Addition applies from left to right in the stem part of the word and a trough-first Beat Addition applies from right to left in the post-stem (suffixal) part of the word.

\section{Prestress Initial}

Recall that in the examples which we have seen so far Beat Addition applied in the domain of either phonological words or phrases, depending on the example. In no single instance would Beat Addition be applicable in both of these domains at the same time. However, such instances are not difficult to come by. Let us look at the phrase do rewolucjonist $+y$ (gen.sg.) 'to the revolutionary' and od konstantynopolitańczyk $+a$ (gen.sg.) 'from the inhabitant of Constantinople'. We shall obtain different derivational outputs depending on whether Beat Addition applies in the domain of words or in the domain of phrases. In (34a) below we assume this latter possibility while in (34b) the former:

(34a) do rewolucjonisty

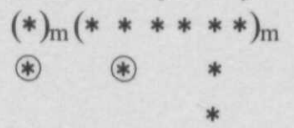

(34b) do rewolucjonisty

$(*)_{\mathrm{m}}(* * * * * *)_{\mathrm{m}}$

$\circledast * *$

$\star$ od konstantynopolitańczyka

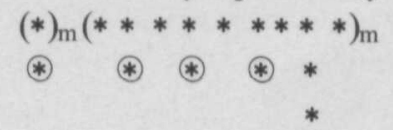

MSR (13)

NSR (18)

BA (27)

od konstantynopolitanczyka

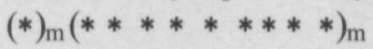

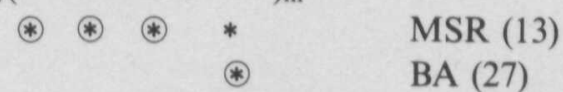

As a matter of fact both (34a) and (34b) are incorrect. In (34a) the pattern is completely wrong: the second syllable in each noun can never be stressed. The pattern given in (34b) can easily be corrected. It is only necessary to assume that Polish has a rule Prestress Initial: ${ }^{8}$

8 Rule (35) can be seen as a language-specific implementation of the general rhythmic principle that we discuss. However, it does not follow from (55): the stress has to move even when there is a space of one syllable. 
(35) Prestress Initial *

Rule (35) moves the initial stress in (34b) to the phrase initial position. The output is then correct.

Prestress Initial is a euphony rule of phrase phonology. It guarantees that no phonological phrase can start with the pattern: trough in the neighbourhood of a following rhythmic peak. In many instances the application of Prestress Initial is pre-emptied by Beat Addition. Compare the derivation of ten rewolucjonista 'this revolutionary' and ten nasz rewolucjonista 'this (our) revolutionary':

(36) ten rewolucjonista

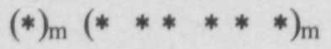

$\leftarrow$ ***

* ten nasz rewolucjonista

$(*)_{\mathrm{m}}(*)_{\mathrm{m}}(* * * * * *)_{\mathrm{m}}$

* $\quad * \quad * \quad$ MSR (13)

* $\quad$ BA (27)

* (circled aster.)

NSR (18)

BA (27)

(boxed aster.)

Prestress Initial

(35) (arrow)

In (37) below we give further examples to illustrate the operation of Beat Addition in the domains of the phonological word and the phonological phrase:

(37a) jak on by protestowal $(*)_{\mathrm{m}} \quad(*)_{\mathrm{m}} \quad(*)_{\mathrm{m}} \quad(* * * *)_{\mathrm{m}}$

*

(*) *

(*)

$\operatorname{MSR}(13)$

BA (27)

mot

* $\quad$ (circled asterisks)

NSR (18)

BA (27)

(boxed asterisk)

'How would he protest.' 
(37b) on by protestowal

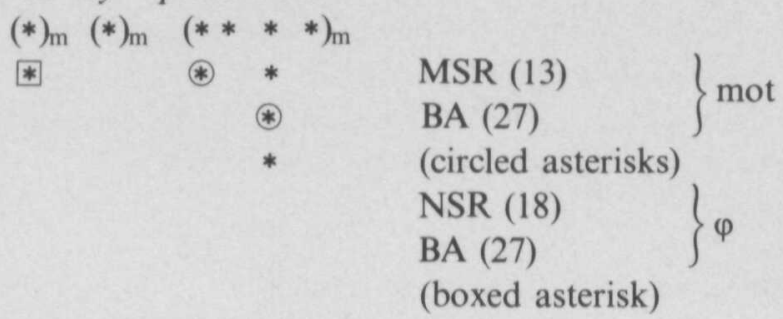

'He would protest.'

Our derivations demonstrate that Beat Addition reapplies after every textto-grid rule, i.e., after rules which are sensitive to the context not contained in the grid (MSR and NSR). This is very much in keeping with Selkirk's (1984) observations about the nature of euphony rules. Note also that rules apply in a stepwise manner from smaller to larger prosodic domains in accordance with the order in which these domains are unveiled or created. We have a prosodic cycle. ${ }^{9}$

\section{Compounds}

\subsection{Compound Stress Rule}

Consider the following compound words :

$$
\begin{aligned}
& \text { (38) } r z e c z+o+z n a w c+a=\left(\left(\check{z ̌}^{2} e \check{c} o\right)_{\mathrm{m}}(z n a f c a)_{\mathrm{m}}\right)_{\mathrm{m}} \cdot \text { 'expert' } \\
& c u d z+o+z i e m i e c=\left((c u d z o)_{\mathrm{m}}\left(\dot{z}^{1} e m j e c\right)_{\mathrm{m}}\right)_{\mathrm{m}} \text { ' 'foreigner' } \\
& c z e s k+o+\text { polsk }+i=\left(\left(\check{c}^{2} e s k o\right)_{\mathrm{m}}(\text { pólski })_{\mathrm{m}}\right)_{\mathrm{m}} \cdot \text { 'Czech-Polish', etc. }
\end{aligned}
$$

The second constituent of the compound is stronger. Notice, however, that these quadrisyllabic compounds have a stress pattern that is identical to

9 Let us emphasize that the cycle is prosodic and not morphological. Therefore the analysis at hand is not comparable to the well known analysis of cyclic stress in English. 
quadrisyllabic simple words. An offhand suggestion is to treat compounds as if they were simple words from the prosodic point of view. This in fact is incorrect (but see section 9 below).

In longer compounds the basic word stress of both constituents is preserved, yet the second part of the compound is stronger :

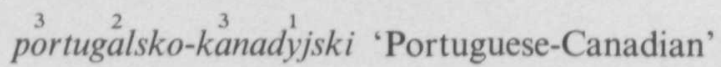

konstytucyjno-parlamentarny $^{3}$ 'constitutional parliamentary'

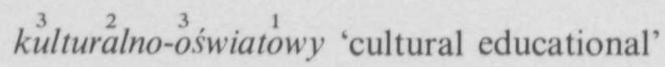

( $1=$ strongest stress $; 2=$ second strongest stress; $3=$ rhythmic stress $)$

It looks as if the extra strength on the second constituent could be simply added by NSR (18). The pattern of weaker stresses will be correctly derived by MSR (13) applying separately to each constituent and by Beat Addition (27).

However, there is some evidence that compound prominence should not be attributed to NSR but rather to a separate rule which applies exclusively to compounds. This evidence, originally brought to light by Dogil (1979), can be drawn from an analysis of nouns followed by adjectives. A vast majority of such collocations have the expected strongest stress on the second word:

(40) Ốgród Zoologiczny 'Zoo', kościól protestancki 'Protestant church',

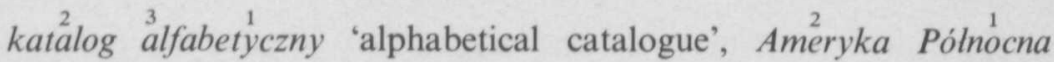
'North America', Uniwersytet Warszawski 'University of Warsaw', ${ }^{10}$ etc.

Clearly the strongest stress in these noun plus adjective phrases is derived

10 One should analyse these data with great caution as one may easily misinterpret the facts and take the emphatic stress pattern for the permanent (normal) pattern. Dogil (1979) has discovered that under emphasis stress moves to the initial syllable or, more generally, to the initial constituent. These phrases may then easily be mistaken for those in (40) below. It seems that the most reliable test to discover the correct pattern is to subject a given phrase to various inflections. It is then clear that only the phrases discussed in (40) below are able to preserve the same pattern. There may be considerable dialectal variation with respect to the distinction between the phrases in (39) and the phrases in (40) below. 
by NSR (18). However, there are also other noun plus adjective collocations in which the strongest stress falls on the first constituent:

(41) gazêtka ścienna 'wall newspaper' (from Dogil (1979:60)), kủa

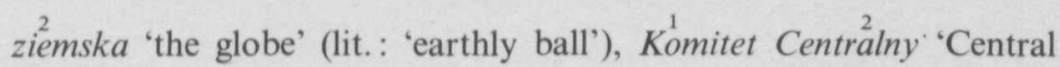
Committee' (in the sense 'of the party'), etc.

It seems that the best way of drawing a distinction between the two arbitrary classes of noun plus adjective collocations: those in (40) and those in (41), is to assume, very much in the same way as is done for English (blackboard vs. black board), that the structures in (41) are compounds while those in (40) are ordinary phrases. Treating the collocations in (41) as compounds would be in keeping with the fact that their semantics is often idiosyncratic and hence they would be best analysed as lexicalizations. We thus have contrasting structures such as the following:

(42) $\left[[\text { katalog }]_{\mathrm{N}}[\text { alfabetyczny }]_{\mathrm{Adj}}\right]_{\mathrm{NP}}$ 'alphabetical catalogue', vs. $\left[[\text { gazetka }]_{\mathrm{N}}[\text { ścienna }]_{\mathrm{Adj}}\right]_{\mathrm{N}}{ }^{11}$ 'wall newspaper'

The stress of the NP is derived via NSR (18). Note, however, that NSR cannot give the correct stress pattern in the noun plus adjective compounds, where the first constituent is more prominent. We therefore need a separate rule for compound stress.

Let us try to discover the environment in which compound stress should apply. In (38) and (39) it is the second constituent of the compound which is stressed while in (41) it is the first. The parameter that they have in common is that of headness: in (38) and (39) the second constituent is the head of the compound while in (41) it is the first. The Compound Stress Rule is thus the following:

11 The fact that in this compound as well as in the others given in (40) both constituents undergo inflection is of little significance. There are structures in Polish whose status as compounds is unquestionable and which, like gazetka ścienna 'wall newspaper', have inflection on both of their constituent parts, e.g., $\left[[\mathrm{Bia}+\mathrm{y}]_{\mathrm{Adj}}[\mathrm{stok}]_{\mathrm{N}}\right]_{\mathrm{N}}$ (name of a city, nom.sg.) $-B i a l+e g o+s t o k+u$ (gen.sg.), $\left[[\text { Wielk }+\mathrm{a}]_{\text {Adj. }}[\text { noc }]_{N}\right]_{N}$ 'Easter' $-W i e l k+i e j+n o c+y$ (gen.sg.)

$\sim$ Wielk $+a+n o c+y$. 
(43) Compound Stress Rule (CSR):

Add a beat to the head.

The notion 'head of a compound' is independently motivated from morphology. Let us point to only a few indications:

(i) the category of the compound is that of its head:

(44) $c u d z+o+$ ziemiec 'foreigner' ( $-o$ is a linking phoneme) :

$$
\text { Adj. }+\mathrm{N}=\mathrm{N}
$$

$k o p+i+$ dolek 'grave digger' ( $-i$ is a linking phoneme) :

$$
\mathrm{V}+\mathrm{N}=\mathrm{N}
$$

$k u l+a$ ziemsk $+a$ 'globe' ( $-a$ is an inflectional ending):

$\mathrm{N}+\operatorname{Adj} .=\mathrm{N}$

(ii) the head decides the inflection of the compound as a whole, e.g., gender :

(45) $r z e c z+o+z n a w c+a$ 'expert': $\operatorname{rzecz}($ fem. $)+$ znawc $+\mathrm{a}$ (masc.) $=$ masculine

$r z e c z+o+z n a w s t w+o$ 'expert knowledge' : rzecz (fem.) + znawstw $+o$ (neuter) $=$ neuter, etc.

\subsection{Prestress Initial}

Compounds whose first constituent is trisyllabic may show variation in their stress pattern:

(46)

$$
\begin{aligned}
& \left((j e ̨ z y k o)_{\mathrm{m}}(z n a w c a)_{\mathrm{m}}\right)_{\mathrm{m}} \quad\left(\left(\text { języko }^{2}\right)_{\mathrm{m}}(z n a w c a)_{\mathrm{m}}\right)_{\mathrm{m}} \cdot \text { 'linguist' } \\
& \left(( \text { daleko } ^ { 2 } ) _ { \mathrm { m } } ( \text { bieżny } _ { \mathrm { m } } ) _ { \mathrm { m } } \quad \left(\left(\text { dáleko }_{\mathrm{m}}(\text { biéżny })_{\mathrm{m}}\right)_{\mathrm{m}} \cdot\right.\right. \text { 'long distance' }
\end{aligned}
$$

(Adj.)

In the first word stress may fall either on the second syllable (as predicted by MSR) or on the first. This variation exists only for some speakers. Others have an obligatory'stress on the first syllable. We have a rule which can readily account for this stress shift: it is Prestress Initial (35): 
(47) jezykoznawca 'linguist' (lit.: 'expert on language')

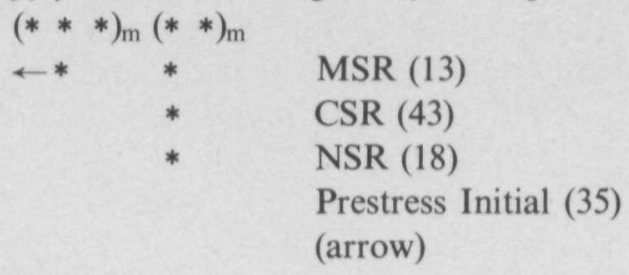

\subsection{Preservation of prominence}

A problem arises when we look at compounds whose first constituent is at least quadrisyllabic and whose second constituent is disyllabic. In these cases Beat Addition applies to the first constituent but not to the second. As a result of this, the main stress of the first constituent is strengthened and the balance of prominence is disturbed. Consider the derivation in (48) below, where we apply rules at the word level only:

(48) kanadyjsko-polski 'Canadian-Polish'

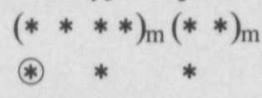

※)
MSR (13)

BA (27)

The problem is resolved easily by applying Halle's (1984) Stress Equalization Convention which we quote in (49):

(49) When two IC's are joined into a single higher constituent, the tallest asterisk columns of the respective constituents are equalized by adding asterisks to the lesser column (Halle (1984)).

Convention (49) adds a beat to polski whose first syllable is strengthened further by CSR. We rewrite the derivation in $(48)$ as $\left(48^{\prime}\right)$ below:

(48') kanadyjsko-polski 'Canadian-Polish'

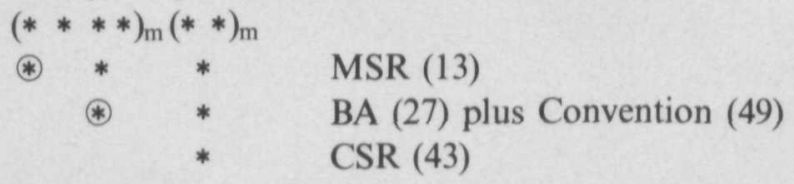


The application of the Stress Equalization Convention (49) in the derivation in $\left(48^{\prime}\right)$ is very much in keeping with the observation which we made earlier (due to Selkirk (1984)) that Beat Addition cannot change prominence relations assigned by text-to-grid rules (MSR in this instance).

\subsection{Phonological structure}

So far we have looked at compounds which consist of two constituents only. A question arises what happens when compounds have multiple constituents. Such structures are commonplace in Polish since the rule of compounding by inserting the linking phoneme $-o$ is fully productive. In fact, it is only common sense that sets a limit as to how many constituents one can have in a compound:

(50) amerykańsko-kanadyjsko-brazylisko- ... -francusk $+i$ (- $i$ is an inflectional ending) 'American-Canadian-Brazilian ... -French' zielono-czerwono-niebiesko- ... -brazow $+y$ (-y is an inflectional ending) 'green-red-blue- ... -brown', etc.

One would expect that in such cases morphological constituent structure at all levels which are lower than the highest projection should play no role in phonology. This is a correct expectation. We capture the generalization just mentioned by claiming that the structure of mot prime (phonological compound) is flat and not hierarchical. The erection of $m^{\prime}$ is therefore a simple adjoinment procedure: $m^{\prime}$ s are gathered into $m^{\prime}$ with no regard to their morphological embedding.

Given this assumption, we predict that the last constituent (which is the head) is stronger in both zachodnio-europejsko-amerykański (see (51a) below) 'Western-European American' and in amerykańsko-zachodnio-europejski (see (51b) below 'American Western-European', where the morphological structure of each compound is different at the lower level. In (51a-b) below we give both the morphological and the phonological structure of these compounds. To save space we use initial letters only ( $m^{\prime}$ erection means the addition of phonological structure): 
(51a)

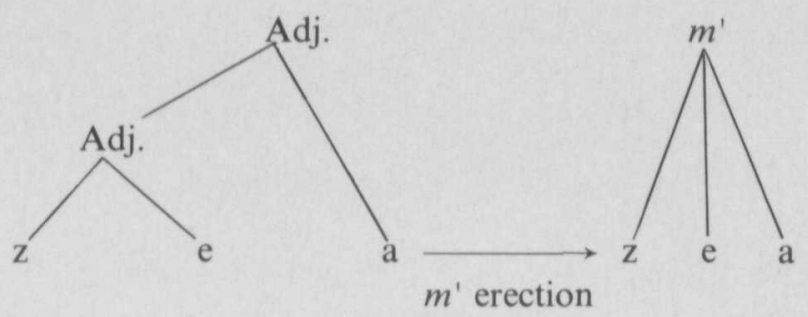

(51b)

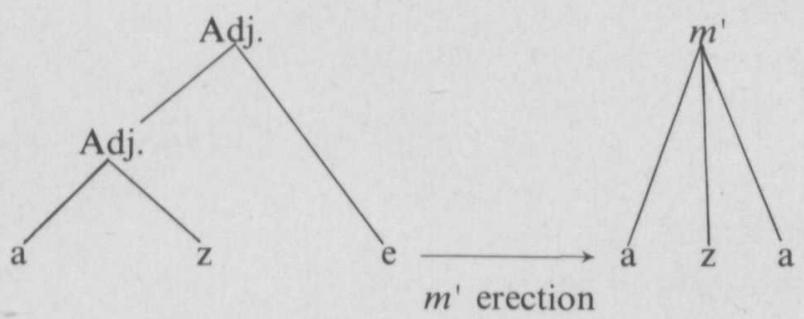

As predicted, the stress pattern of both of these compounds is the same: the first two constituents have equal stress, the last constituent is the strongest.

The differences of structure (morphological vs. phonological) which arise in compounds confirm the well known observation that morphological and phonological constituency may but need not be isomorphic. We have provided yet another example where such isomorphy does not hold (see also Booij and Rubach (1984)).

\section{Stress clashes and eurhythmicity}

Compounds in (52a) below have a stable stress pattern while those in (52b) may optionally undergo a stress shift. In consequence of this shift the stress on the syllable of the first constituent is perceived as stronger than the regular penultimate stress in that constituent:

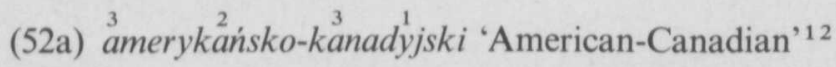

$$
\begin{aligned}
& \text { poludniowo-afrykanski 'South-African }^{2}{ }^{3} \\
& \text { historyczno-literacki 'history of literature' (Adj.) }^{3}{ }^{1} \text { ' }
\end{aligned}
$$

12 One reservation has to be made here: these are the patterns of nonemphatic speech. As discovered by Dogil (1979), in the case of emphasis the strong stress is moved to the constituent initial syllable. 
(52b) kanadyjsko-polski 'Canadian-Polish' materialo[-rjawo ${ }^{2}{ }^{1}$ awstwo 'expert knowledge of materials' fioletowo-czârny [fjoletovočarni $]$ 'violet black', etc.

The stability of the stress pattern in (52a) as compared with (52b) becomes clear when we realize that it is only in (52b) that stress clashes arise:

(53a) amerykańsko-kanadyjski 'American-Canadian'
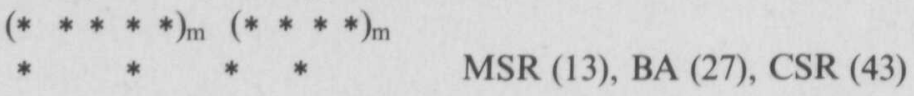

(53b) kanadyjsko-polski 'Canadian-Polish'

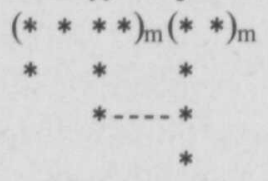

MSR (13), BA (27), CSR (43)

The stress clash in (53b) is resolved by applying the rule Move $x$ (Prince (1983)) which shifts a beat to the initial syllable of kanadyjsko:

(54) kanadyjsko-polski 'Canadian-Polish'

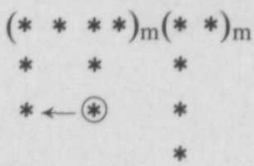

Hayes and Puppel $(1983)^{13}$ have suggested that the shift of stress in (53b) is governed by the universal Quadrisyllabic Rule, which is part of Hayes's rhythmic interval theory:

13 The remarkable thing about this paper is that even though the data are largely wrong, the theory may very well be entirely correct. As pointed out to us by G. Dogil (and we agree with his judgement), all of the Polish examples quoted for movement of stress in Hayes and Puppel (1983) can be regarded as acceptable only if they are interpreted as cases of emphasis. Consequently, Hayes and Puppel's examples show nothing as initial stress for emphasis is used in Polish very regularly (Dogil's (1979) insight) and it occurs in configurations of stress patterns which have nothing to do with stress clashes or with the Quadrisyllabic Rule. One of Hayes and Puppel's examples is incorrect under any circumstances, regardless of emphasis. 
(55) Quadrisyllabic Rule:

A metrical grid is eurhythmic when it contains a row of marks spaced about four syllables apart (Hayes and Puppel (1983)).

The Quadrisyllabic Rule predicts (54). It would also predict correctly that the resolution of clash in (56) below is unlikely since a pentasyllabic interval would produce no improvement in the rhythmic pattern as compared to a trisyllabic interval :

(56) kanadyjsko-polskimi 'Canadian-Polish' (instr.pl.)

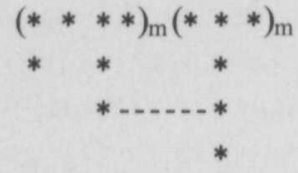

MSR (13), BA (27), CSR (43)

The pattern in (56) seems to be correct in spite of the stress clash. The exact judgement is difficult to make since one must bear in mind that moving the stress to the initial syllable is possible in Polish under emphasis and it may be hard to tell the 'normal' pronunciation from the emphatic one (see footnotes 12 and 3 ).

The resolution of stress clashes is unlikely (emphasis apart) in compounds such as those in (57):

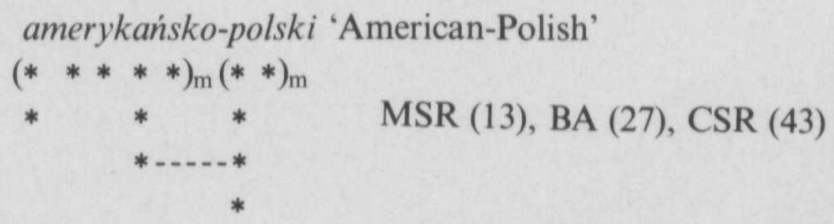

Likewise: socjologiczno-prawny 'sociological legal', literaturoznawstwo 'expert knowledge of literature', etc.

It is the phrase sen Kowalikówny 'Kowalikówna's dream' with the stress being placed on the -wa of Kowalikówny. Hayes and Puppel's choice of data is unfortunate in that they deal with syntactic and not with phonological phrases (in the sense of Dluska (1974), see section 2). In syntactic phrases, which are mappings of phonological phrases, there are independent main stresses and stress clashes are tolerated very regularly. The rightmost constituents are stronger, as predicted by NSR (18). It is therefore only compounds such as those discussed in this section that can throw light on how stress clashes are resolved. Hayes and Puppel's theory seems to be correct. It may indeed be the case that the Quadrisyllabic Rule is the guiding principle in the resolution of stress clashes, as we explain below. 
It is in such cases that the Quadrisyllabic Rule has an advantage over the stress clash theory. In (57) the latter would predict a stress shift, the former correctly does not because the stress could only be moved to the initial syllable, which would not be the rhythmic improvement that the Quadrisyllabic Rule aims at. However, let us also observe that in (57), unlike in the earlier examples, the shifting beat would have to travel two spaces rather than one space to the left. Perhaps then the likelihood of resolving a stress clash depends on how far a given beat would have to travel.

It seems that the Quadrisyllabic Rule may also be usefully employed in accounting for at least some cases of the flattening of rhythmic stresses with the increase in the tempo of speech. The relevant examples are found in (58a-d) below, where the order of flattening (as far as we can judge) is given on the right. The grids are derived by applying MSR (13) and BA (27):

(58a) rewolucjonista 'revolutionary'
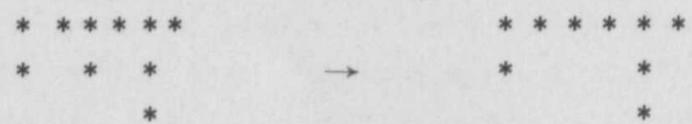

(58b) konstantynopolitańczyk 'inhabitant of Constantinopole'

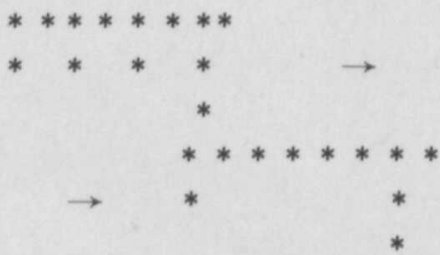

(58c) konstantynopolitańczykami (instr.pl.)

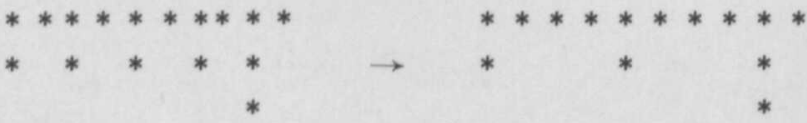

(58d) rewolucjonistami 'revolutionary' (instr.pl.)
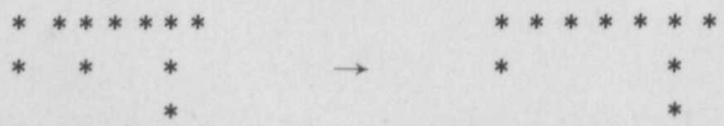

Two comments should be made about $(58 \mathrm{c})$ :

- we give no intermediate stage with three rhythmic stresses since it is very difficult to establish whether it is the second or the fourth stress that disappears first, and 
- the middle stress seems to be obligatory even in very rapid speech, which is not surprising as the word is unusually long.

With the exception of (58d) and the last stage in (58b), the Quadrisyllabic Rule makes a correct prediction as to the order in which internal rhythmic stresses are leveled.

\section{Demoting}

In this and in the following section we shall look at subregularities in the system of Polish stress. These facts do not bear on the issue of grids versus trees. Yet, the subregularity analysed in this section is of special interest since we seem to have a case where prosodic structure is partially erased while the morphological structure remains intact.

\subsection{Compounds}

Consider the following compounds ( $-i$ is the linking phoneme if the first constituent is a verb, $-o$ if it is not a verb) :

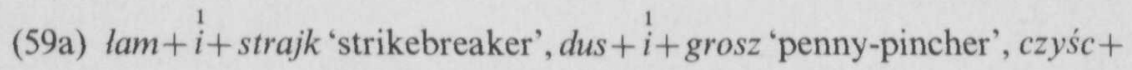
$\stackrel{1}{i+b u t}$ 'shoe cleaner', pas $+\stackrel{1}{i+b r z u c h}$ 'glutton'

(59b) radi $\stackrel{1}{\circ}+$ wó $z$ 'police car', mars $z+\stackrel{1}{o}+$ bieg 'marching and running' $(-i$ is $/ j /$ in this and in the preceding example), $f a l+\stackrel{1}{o}+$ chron 'breakwater', żólt $+\stackrel{1}{o}+d z i o ́ b$ [žuwtodźup] 'greenhorn'

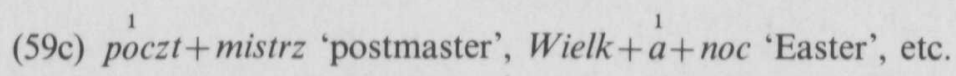

As has long been observed, compounds such as those in (59) have the stress pattern of simple words: stress falls on the penult. When inflectional endings are appended, the stress pattern is that of normal compounds:

(60a) ciśnieni $+o+$ mierz [ćíśnenomješ] ${ }^{14}$ 'pressure indicator' (nom.sg.) : no ending

14 Accents over consonants denote palatalization: see footnote 2. 
vs. :

(60b) ciśnieni $+o+$ mierz $+e$ [ćiśńeńomježe] (nom.pl.) [ćiśńeńomježe]

(60c) ciśnieni +o+mierz + ami [ćiśńéńomježami] (instr.pl.)

Likewise: szybkości+o+mierz 'speedometer', potencj+o+metr 'potentiometer', etc.

Thus it is only compound forms such as those in (59) and (60a) that behave like simple words. (Recall also the other compounds which we discussed in sections 7 and 8.)

The subregularity at hand should be captured by a rule of 'demoting', which erases the prosodic structure: compound phonological word. The rule applies if the second constituent of the compound is monosyllabic:

(61) Demoting

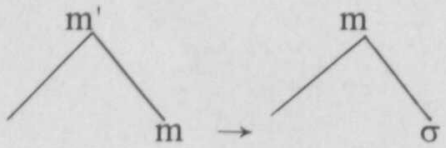

$\sigma$

Speakers who have an obligatory secondary stress on the first syllable in (60b) (see the form on the right) have a slightly different rule of Demoting. In their dialect Demoting applies if the second constituent of the compound is either mono- or disyllabic. This is the dialectal variation that we mentioned earlier when discussing the stress pattern of jezykoznawca 'linguist' in section 7.2 .

Nothing needs to be said about the 'irregular' compounds considered here. After Demoting they undergo MSR (13) and a correct stress pattern is derived without difficulty.

\subsection{Lexicalized phrases}

Compare the stressing of the prepositional phrases in (62) below, where they are given in a wider context to bring out the semantic differences (for lack of space we restrict our examples to the preposition na): 
(62) na wieś [na v'jéś] napadli Tatarzy

'Tartars attacked the village.' vs. :

wyjechał ná wieś

'He went to the country (lit.: 'village').'

na dwór królowej

'To the queen's court.' vs. :

wyszedł nà dwór

'He went out.'

na noc składa sie okres od...

'Night is composed of a period of ...' vs. :

zostanę ná noc

'I shall stay for the night.', etc.

As predicted by NSR (18), the normal stress pattern is that found in each upper line in (62). The phrases in each lower line (note the contrast) are clearly lexicalized. Therefore they are derived in the lexicon. This conjecture is additionally supported by the fact that there are phrases whose pattern is exactly the same as that of the phrases in each lower line in (62) and which need to be listed for reasons independent of stress. These are the phrases discussed in Rubach (1984b) such as we dnie [ve dńe] 'in daytime', ${ }^{1} e^{1} w s i$ 'from the country', spode lba 'suspiciously' (lit.: 'from under (his) head'), etc. They are inputs to the rule of Lower which is a lexical and not a postlexical rule (cf. Rubach (1984a) and (1984b)).

We suggest that the phrases with the irregular stress pattern be regarded as lexicalized. From the point of view of their phonological structure they should be interpreted as compounds. They can then undergo Demoting (61). MSR (13) derives the correct pattern. On the other hand, the regular phrases found in each upper line in (62) are derived syntactically. They arise outside the lexicon and hence from the point of view of phonology they are phrases and not compounds. NSR (18) assigns stress as required. 


\section{Residual problems}

There are four further subregularities that need to be mentioned in order to have a complete overview of all the issues in the Polish stress system at the level of phonological words and phrases.

\subsection{Monosyllabic preposition plus pronoun structures}

It is an arbitrary fact of Polish that prepositional phrases consisting of a monosyllabic preposition and a monosyllabic pronoun receive stress on the preposition:

(63) do nas 'to us' vs. do drzew 'to the trees' na was 'on you' vs. na dom 'on the house' przed nim 'in front of him' vs. przed psem 'in front of the dog', etc.

- One way of solving the problem would be to suggest a rule of Demoting. However, this rule would have to be different from Demoting (61) which applies to compounds. Therefore this solution is not particularly attractive. We suggest that Polish simply has rule (64):

(64) Preposition Rule:

Add a beat to the preposition in the structure : preposition pronoun. ${ }^{15}$

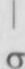

$\sigma$

10.2. nie plus monosyllabic verb

As is well known, nie 'not' is stressed if it appears before a monosyllabic verb:

15 There is one well known further exception. The preposition kolo 'near' (but no other disyllabic prepositions) behaves as if it were monosyllabic when in front of a pronoun, compare koló nas 'near us' vs. the regular kồlo lásu 'near the wood'. One way of solving the problem is to assume that kolo has an allomorph with an extrametrical ko- and that it is this allomorph which appears before pronouns. Given that ko- is extrametrical, kolo nas 'near us', etc. can undergo rule (64). 
(65) nie wiem [n'e v'jem] 'I don't know' vs. :

czy wiem [či v'jem] 'do I know', jak wiesz [jag v'ješ] 'as you know', etc.

A way out of the dilemma is to treat nie as a prefix. This interpretation is supported by the following two observations:

(i) nie is a prefix in the structures nie + Adj. and nie $+\mathrm{N}$ : niemily 'unpleasant', niedrogi 'inexpensive', nietakt 'tactlessness', niewiedza 'ignorance', etc.,

(ii) there are nie nouns which come from verbs via back derivation: nierób 'loiterer', 'do nothing' $\leftarrow$ nie robić 'not to do', nieuk 'ignorant' $\leftarrow$ nie $u c z+y+\dot{c} / / \mathrm{uk}+\mathrm{i}+\dot{\mathrm{c}} / /$ 'not to learn', etc.

If nie is recognized as a prefix also in verb structures, ${ }^{16}$ then the irregularity mentioned in (65) disappears altogether : nie wiem 'I don't know' is derived via MSR (13).

\subsection{Initials}

As is often pointed out, initials take stress on the last constituent of a sequence :

(66) $K C\left[\mathrm{ka} \quad \mathrm{cc}^{1}\right]$ 'Central Committee', NRD [enerde] 'GDR', ZSRR [zéteserer] 'USSR', etc.

The stressing of initials is perfectly productive and exceptionless. It must therefore be accounted for by postulating a rule.

\subsection{Numerals}

The numerals for $400,500,600,700,800$ and 900 have antepenultimate stress, e.g., czter $+y+s t+a$ [čterista] 'four hundred', siedem + set [śedemset]

16 The fact that nie is spelled separately with verbs but not with adjectives or nouns is no more than an orthographic convention. It should also be noted that nie has a double function in Polish. It is a prefix and also a separate word which is used in the sense 'no'. 
'seven hundred', osiem + set [ośemset] 'eight hundred'. ${ }^{17}$ One way of dealing with this problem is to assign them to the class I words which undergo Extrametricality (10) from section 3 . We then predict correctly that the instrumental form $c z t^{2} r+y+s t+\stackrel{1}{\text { oma }}+$ 'four hundred' has a regular stress pattern. Like all other class I words, these numerals have a tendency to regularize, i.e., to develop a penultimate stress: $c z t e r+\stackrel{1}{y}+s t+a$ 'four hundred', etc.

\section{Conclusion}

In conclusion we summarize the most important theoretical results of this paper.

We have worked with the grid theory in an attempt to see whether the grid mechanism could be regarded as adequate for the description of Polish stress. We conclude that this is the case. In particular, the grid theory has an advantage over the classical arboreal paradigm (Selkirk (1980)) with respect to the description of secondary stress: the grid is the mechanism par excellence for the expression of rhythmic alternation which is independent from Main Stress Assignment. Prosodic restructuring rules (for cases such as Pre-stress Initial and optional secondary stress) are no longer necessary. Also, as pointed out by Dłuska (1974), Polish monosyllables are grouped around a polysyllabic word to form a phonological phrase. Their stress pattern is purely rhythmic and hence it seems natural to assume that they do not carry any inherent stress assigned by the Main Stress Rule. The surface pattern is derived by Beat Addition which constructs a pattern of alternating stresses.

Our claim that the grid mechanism is adequate for the description of Polish stress should not be taken to imply that arboreal structure has become completely superfluous. Prosodic categories such as the syllable and the phonological word remain in power. They function as domains for grid construction and for phonological rules. It is only the prosodic category 'foot' which has become superflous. Neither is the strong/weak labeling of prosodic trees necessary any longer.

From the typological point of view Polish is interesting in that its

17 In the case of 'five hundred' and 'six hundred' this can be seen in the genitive: pieci $u+$ set [p'jếńćuset], sześci $+u+$ set [sésćuset]. In the nominative they are disyllabic : pieć + set, sześć + set. 
primary stress functions as a focus for rhythmic stresses. Beat Addition works its way towards the main stress from left to right for syllables standing before the main stress and from right to left for syllables standing after the main stress. In the former case Beat Addition starts with a peak while in the latter it begins with a trough. We have seen that a similar situation obtains for Dutch.

As regards extrametricality in Polish, we wish to draw attention to the fact that it calls for a high degrees of abstractness. In particular, the treatment of extrametricality lends support to the independently motivated claim that Polish has a set of abstract vowels which undergo absolute neutralization.

Let us also point out that the analysis of compounds (see sections 7.4. and 9) provides arguments to substantiate the well known observation that phonological structure need not be isomorphic to morphological structure.

Finally, the resolution of stress clashes in Polish seems to show preference for a quadrisyllabic pattern of alternation.

\section{References}

Booij, G.E. and J. Rubach, 1984. Morphological and prosodic domains in lexical phonology. Phonology Yearbook 1, 1-25.

Dłuska, M., 1957. Akcent i atona w języku polskim. Studia z filologii polskiej i słowiańskiej 2, 92-121.

Dłuska, M., 1974. Prozodia języka polskiego. Warszawa: Państwowe Wydawnictwo Naukowe.

Dogil, G., 1979. Autosegmental account of phonological emphasis. Edmonton: Linguistic Research.

Franks, S., 1985. Extrametricality and stress in Polish. Linguistic Inquiry 16, 144-151.

Gaertner, H., 1938. Gramatyka współczesnego języka polskiego. Lwów-Warszawa: Książnica Atlas.

Halle, M., 1984. Grids and trees in metrical phonology. A paper given at the 5th International Phonology Congress, Eisenstadt, 24-28 June 1984. To appear in: W. U. Dressler (ed.), Phonologica 1984. Cambridge: Cambridge University Press.

Halle, M. and J.-R. Vergnaud, 1984. Grids and trees. Cambridge, MA: Unpublished MIT ms.

Hayes, B. and S. Puppel, 1983. On the Rhythm Rule in Polish. Los Angeles, CA: Unpublished UCLA ms.

Hayes, B., 1984. The phonology of rhythm in English. Linguistic Inquiry 15, 33-74.

Hulst, H. van der, 1984. Syllable structure and stress in Dutch. Dordrecht: Foris Publications.

Pike, K. L., 1964. Stress trains in Auca. In: R.M. Brend (ed.), K. L. Pike's Selected Writings (1972), 186-191. The Hague: Mouton.

Prince, A.S., 1983. Relating to the grid. Linguistic Inquiry 14, 19-100.

Rubach, J., 1974. Syllabic consonants in Polish. Journal of Phonetics 2, 109-116. 
Rubach, J., 1984a. Cyclic and lexical phonology. The structure of Polish. Dordrecht: Foris Publications.

Rubach, J., 1984b. Lexical and postlexical derivations in lexical phonology. A paper given at the 5th International Phonology Congress, Eisenstadt, 24-28 June, 1984. To appear in: Phonology Yearbook 2 (1985). Cambridge: Cambridge University Press.

Scalise, S. and I. Vogel, 1982. Secondary stress in Italian. Lingua 58, 213-242.

Selkirk, E.O., 1980. The role of prosodic categories in English word stress. Linguistic Inquiry 11, 563-606.

Selkirk, E.O., 1984. Phonology and syntax: The relation between sound and structure. Cambridge, MA : MIT Press. 